\title{
Can the battle against climate change become an effective social movement?
}

\author{
John C. Dernbach* \\ Widener University Law School, 3800 Vartan Way, PO Box 69381, Harrisburg, Pennsylvania 17106, USA
}

This is an especially challenging time for discussions of serious action to address climate change in the United States. As Lemons \& Brown (2011) explain, the scientific and ethical case for serious reductions in greenhouse gas emissions is compelling. They provide a summary of recent scientific reports indicating the importance of having an emissions peak in the very near future and a decline sharply thereafter in order to reduce the risk of destabilizing climate change. They also point out that global climate change raises ethical issues because, while developed countries bear most of the responsibility for increased greenhouse gas emissions, people in developing countries will suffer the most. The effects of climate change are 'potentially catastrophic' for many of the world's poor (FAO 2011). Because most of the increase in atmospheric greenhouse gas concentrations comes from outside any particular country, and because there is not yet an effective international legal structure to reduce greenhouse gas emissions, 'ethical appeals are necessary to motivate governments to take steps to prevent their citizens from seriously harming foreigners' (Lemons \& Brown 2011, p. 7).

Still, ethical appeals and strong scientific evidence have not been enough to motivate action. Recent events, including the global economic recession, the public release of hacked climate scientist emails from the University of East Anglia, the failure of the United States to adopt climate change legislation and the 2010 US midterm elections, have made it much harder for those arguments to be heard, much less to be addressed civilly. Within the community of people who are working to address climate change, there has thus been considerable soul searching about how to proceed more effectively. The suggestion by Lemons \& Brown (2011) — that climate and environmental scien- tists and the public consider whether non-violent civil disobedience should be used to promote action on climate change - comes in the context of these recent events.

Their suggestion should be considered as part of an approach that does not rely on any single action, but rather on a great number and diversity of actions. Two points seem particularly important and are discussed below.

\section{(1) CLIMATE CHANGE MITIGATION HAS NOT YET BECOME A BROAD SOCIAL MOVEMENT}

According to Brownlee (2009), non-violent civil disobedience is characterized 'by the seriousness, sincerity and moral conviction with which' those who use civil disobedience breach the law, by the desire of those involved to condemn and draw public attention to a particular law or policy, and by acts of disobedience that are carried out in full view of the public. Non-violent civil disobedience is one of many forms of protest or dissent, including lawful protest, conscientious objection, radical protest, and revolutionary action. Another form of protest or dissent occurs when government officials refuse to enforce a particular law (Brownlee 2009). Non-violent civil disobedience is not ordinarily an isolated act; it is done as part of a social movement or to inspire or instigate the creation of such a movement.

It does not appear that there is a broad public movement demanding government action on climate change in developed countries of the kind that has existed for other social causes. We have not seen, for example, a massive demonstration by hundreds of thousands of people at the National Mall in Washing- 
ton, DC, or elsewhere. On its homepage, the website www.350.org says that 'we are building a global movement to solve the climate crisis,' but its rallies around the globe have each been much smaller. While polling data tend to show public support for government action, responding to a poll is hardly the same as participating in a social movement. At least one author has suggested that those advocating action on climate change have relied too much on powerful and wellconnected political figures and environmental leaders, and have not done enough to engage public support (Pooley 2010).

Climate change seems different from other issues that have led to social movements in that nearly everyone in developed countries has some responsibility for greenhouse gas emissions. In many other social movements, there has been a recognizable difference between, say, those who owned slaves and those who did not, between victim and perpetrator. Although many of those active on climate change have worked toward carbon neutrality in their personal lives and in their work, it is probably fair to say that most of those who are active in developed countries are not carbon neutral. In fact, it is not even clear how a particular individual or organization could be entirely carbon neutral, except by acquiring carbon offsets for all of the goods and services they use to more than compensate for the carbon impact of those goods and services. There are simply too many unresolved methodological issues about carbon accounting to be sure, except in some unusual cases, that one is genuinely carbon neutral. So it is more difficult to organize a social movement within developed countries that is based on a clear and easily understood distinction between the 'relatively guilty' and the 'relatively innocent.'

A second challenge in creating a social movement is that climate change is less visible, less tangible, more in the future, and harder to clearly identify than other problems around which social movements have been organized. Even catastrophic events, like those caused by Hurricane Katrina in 2005 or the Pakistan floods in 2010, are simply events that appear to have been made worse by increased greenhouse gas concentrations, not events that were caused entirely by humaninduced climate change. In contrast, the modern environmental movement, which began in the 1960s with the publication of 'Silent spring' (Carson 1962), was based on public unhappiness with the all-too-visible effects of pollution and waste-including the decline of bird life and obviously polluted air and water-that could not be attributed to any other cause.

One can thus conclude that there is a growing public movement in developed countries to address climate change, but it is still relatively small. There is also, it should be said, a significant opposing movement, funded largely by fossil fuel interests and their allies. This opposing movement has had considerable success in creating public doubt and confusion about both climate science and the legal and policy options that are available to address climate change.

A recent book by Appiah (2010) suggests an interesting but so far unrealized possibility for creating a social movement in developed countries to address climate change. Appiah (2010) argues that some of the most important moral revolutions in recent years have come about because people see a particular action as not merely morally right but also as bringing honor or esteem to those who support that action, and shame or loss of esteem to those who do not. Upper or privileged classes supported some practices, such as dueling (Europe, United States) or foot binding (China), until these practices no longer brought esteem but instead brought ridicule or shame. While there were longstanding arguments that these practices were immoral or wrong, those arguments were ultimately not successful until they were linked with loss of honor or social esteem.

Could Appiah's (2010) insights help support a public movement to address climate change? In developed countries, there is a tendency for the wealthiest people to consume more than poorer people, and for that consumption to be a source of higher status. Higher status tends to be linked to bigger cars, bigger houses, and more property and other luxuries. Imagine, in contrast, that being carbon neutral, or having a small ecological footprint, is seen in developed countries as a source of honor or esteem, and that high consumption is a source of ridicule or shame. That change in perception could provide the basis for a moral revolution on climate change, but we seem to be a long way from that point at present.

The path to a social movement to address climate change may be clearer for developing countries. The ethical claim is that people in developing countries, who have the least responsibility for increased greenhouse gas emissions and the fewest resources to address or adapt to climate change, are bearing and will continue to bear the brunt of adverse climate change impacts. Developing countries are increasingly well organized and vocal at the annual meetings of the Conference of the Parties to the United Nations Framework Convention on Climate Change, including Copenhagen in 2009 and Cancún in 2010. There are enormous differences in wealth and carbon impact among people in individual developed countries. In addition, the tremendous growth in Gross Domestic Product and carbon dioxide emissions in China and India has begun to make the distinction between developed and developing countries less 
clear. Still, differences between developed and developing countries in per-capita emissions, impacts, and ability to address impacts provide some foundation for a social movement in developing countries to address climate change. That possibility should be of enormous concern to leaders and citizens in developed countries.

\section{(2) PROTESTS AGAINST POWER PLANTS MAY (OR MAY NOT) BE THE BEST APPROACH TO INSTIGATE A SOCIAL MOVEMENT}

The key example of non-violent civil disobedience cited by Lemons \& Brown (2010) - the 2007 protest at the Kingsnorth coal-fired power plant in England in which activists were arrested on charges of trespass and damage to property after they climbed the plant's smokestack - serves as a useful and important starting point for a discussion. However, it also raises some cautionary flags.

The most natural and direct understanding of civil disobedience is refusal to obey a law that is believed to be unjust; in 1846, Henry David Thoreau was jailed for not paying a poll tax that was used to fund Fugitive Slave Law enforcement as well as a war in Mexico with which he disagreed. The laws relevant to climate change tend to be different. While it is difficult to get along in modern society without causing or contributing to greenhouse gas emissions, few if any laws require such gases be emitted. There is a considerable tradition of non-violent civil disobedience being used indirectly, as it was in the Kingsnorth case, to break laws with which the protesters do not disagree (trespass, property protection) in order to protest against something they object to (carbon dioxide emissions). Yet this is not quite the same, and may not be as compelling, as disobeying a hypothetical law that requires greenhouse gas emissions.

The necessity defense is also problematic. Most obviously, the successful assertion of a necessity defense means that the action in question is no longer civil disobedience; the action is legal. As already noted, lawful protest is another means of protesting or dissenting from a particular policy, but it is not the same as non-violent civil disobedience.

In addition, it is quite difficult to succeed with the necessity defense. The defense is available in English law 'when a defendant commits an otherwise criminal act to avoid an imminent peril of danger to life or serious injury to himself or towards somebody for whom he reasonably regards himself as being responsible' (Regina v. Shayler, [2001] EWCA Crim 1977 [63], [2001] 1 W. L. R 2206 [2228]). Yet, the defense succeeds only rarely. Most famously, a court in 1884 upheld the murder conviction and rejected the necessity defense of 3 shipwrecked and starving sailors who killed and ate the cabin boy (Regina v. Dudley and Stephens, [1884] 14Q.B.D. 273). (The rules in American law are similar; Pearson 1992.)

While the necessity defense persuaded a jury to acquit the defendants in the Kingsnorth case, it did not persuade a judge in a similar 2007 case. In that case, at least 10 people trespassed on the site of the Ratcliffe on Soar coal-fired power plant in the United Kingdom with the intention of disrupting operations at the plant. Some of the protesters chained or otherwise attached themselves to machinery or other equipment. The court found that they targeted this particular plant because it is a large emitter of carbon dioxide and because they were genuinely concerned about the effects of climate change. In fact, the protest resulted in a slight decrease in electricity generation from the plant for several hours. The court analyzed the necessity defense, element by element, and held it to be inapplicable (Regina v. Glass 2008).

The first requirement for the necessity defense is that 'the defendants' actions were necessary, or reasonably believed by them to have been necessary for the purpose of avoiding or preventing death or serious injury to themselves or another or others.' (Regina v. Glass, [2008] M.C. (Nottingham) [39] (25 February 2008)). The court held that this requirement was not met because a reduction in operation at the plant for several hours was highly unlikely to have any effect on climate change. Even though the defendants genuinely believed that climate change is a serious issue, and the judge accepted the seriousness of the climate change science, the court found that they could not reasonably have believed they were actually preventing death or serious injury to others.

The court also found that the second requirement, 'that necessity was the sine qua non of the commission of the crime,' (Regina v. Glass, [2008] M.C. (Nottingham) [47] (25 February 2008)) was not met. The court found that the defendants were not impelled by the claimed necessity to commit the crime; they were concerned by climate change in general and were aware of the publicity their actions would generate.

Third, the court held that the defendants did not meet the requirement that 'commission of the offence, viewed objectively, was reasonable and proportionate, having regard to the evil to be avoided or prevented.' (Regina v. Glass, [2008] M.C. (Nottingham) [48] (25 February 2008)). The court based its conclusion on the information and analysis already provided. 'Reasonable people may take action to limit their own 'carbon footprint' and may campaign for more urgent action by governments, but attempting to stop a large power station from functioning is, in my judgment, a step too far 
for the reasonable person.' (Regina v. Glass, [2008] M.C. (Nottingham) [51] (25 February 2008)).

This decision - by a judge in the Nottingham Magistrates' Court in the United Kingdom - is almost certainly not the last word on the effect of the necessity defense on the climate change issue. However, it suggests what those who engage in non-violent civil disobedience are well aware that they risk (even invite) real consequences for their actions. It is thus important in considering such actions to be aware of how the legal rules actually work, and not simply to be hopeful that they will always work in a favorable way.

As Lemons \& Brown (2011) acknowledge, there are also political risks to non-violent civil disobedience. Protests such as that at the Kingsnorth coal-fired power plant draw attention to the issue of climate change, but they also enable opponents to point out that the electricity for a great many people (perhaps even some of the protesters) comes from this plant. Such protests thus run the risk of alienating a substantial percentage of the population as well as inviting critics to assert that the protesters are hypocritical. These and other political risks could be overcome with proper planning of a protest event, but they are quite real.

Finally, Lemons \& Brown (2011) are not clear about who should consider engaging in this kind of civil disobedience. In the abstract for their paper, they suggest that environmental and climate scientists do so. In the text of the paper, however, they suggest that all citizens have that responsibility. The latter view is preferable because the climate change is a public issue, and not an issue for any one group or profession. While I respect and admire Dr. James Hansen, who played a key role in the Kingsnorth case described by Lemons \& Brown (2011), it is not clear that this is the best role for all scientists to play, or even a role that they are generally and uniquely equipped to play.

Editorial responsibility: Darryl Macer, Bangkok, Thailand

\section{CONCLUSION}

Non-violent civil disobedience is one of many possible tools that should be considered to help build a social movement to address climate change. The real issue for J. Lemons and D. A. Brown, in my view, is the need for effective political action to address climate change. Their paper (Lemons \& Brown 2011) may be understood as an effort to help provoke a dialogue on the best way to do that. This in itself is a significant contribution. The shape of that movement-and the exact role that non-violent civil disobedience, lawful protest, or other actions should play in it-require serious consideration.

\section{LITERATURE CITED}

Appiah KA (2010) The honor code: how moral revolutions happen. WW Norton, New York, NY

Brownlee K (2009) Civil disobedience. In: Zalta EN (ed) The Stanford encyclopedia of philosophy. Available at http://plato.stanford.edu/archives/spr2010/entries/civildisobedience/

Carson R (1962) Silent spring. Houghton Mifflin, New York, NY

FAO (Food and Agricultural Organization of the United Nations) (2011) Climate change and food security in the context of the Cancún agreements. Available at www.fao. org/news/story/en/item/54337/icode/

Lemons J, Brown DA (2011) Global climate change and nonviolent civil disobedience. Ethics Sci Environ Polit 11:3-12

Pearson JO (1992) 'Choice of evils,' necessity, duress, or similar defense to state or local criminal charges based on acts of public protest. American Law Reports, 5th edn 3:521

Pooley E (2010) The climate war: true believers, power brokers, and the fight to save the earth. Hyperion, New York, NY

Regina v. Dudley \& Stephens (1884) Queen's Bench Division $14: 273$

Regina v. Glass (2008) Nottingham Magistrates' Court

Regina v. Shayler (2001) House of Lords. 1 WLR 2206

Submitted: January 31 2011; Accepted: February 15, 2011

Proofs received from author(s): April 30, 2011 